\title{
Asserting racism's relativity: an interpretive and functional discourse analysis of Flemish nationalist re-articulations of the problematic of racism
}

\section{Jan Zienkowski}

To cite this article: Jan Zienkowski (2017) Asserting racism's relativity: an interpretive and functional discourse analysis of Flemish nationalist re-articulations of the problematic of racism, Journal of Multicultural Discourses, 12:2, 149-165, DOI: 10.1080/17447143.2017.1318887

To link to this article: http://dx.doi.org/10.1080/17447143.2017.1318887

$$
\text { 曲 Published online: } 11 \text { May } 2017 .
$$

Submit your article to this journal $\square$

Џ Article views: 73

Q View related articles $\sqsubset$

View Crossmark data 5 


\title{
Asserting racism's relativity: an interpretive and functional discourse analysis of Flemish nationalist re-articulations of the problematic of racism
}

\author{
Jan Zienkowski \\ Institute for Culture and Society, University of Navarra, Pamplona, Spain
}

\begin{abstract}
This paper focuses on a controversial nationalist discourse that asserts that racism is [a] relative [concept]. It provides a discourse analysis of the functions these assertions and surrounding claims on racism perform in relation to the definitions of racism used, the interpretive repertoires and logics in which they are embedded, and the political project they support. Racism-isrelative discourse reserves the signifier of racism for discrimination on the basis of race and/or descent. It blocks off and delegitimizes critical anti-racist repertoires and notions such as structural racism, racism as ideology, entitlement racism or racism as white privilege. It serves as a shield against accusations of racism. It is integrated with the interpretive repertoire of new realism and with widespread neoliberal and culturalist logics. These patterns do not only characterize discourse on racism's relativity in Flanders but can be found across Europe in contexts marked by low degrees of political awareness regarding racism's many faces. The analysis is based on an interpretive and functional heuristic for doing discourse analysis based on a notion of discourse understood as articulatory practice.
\end{abstract}

\section{ARTICLE HISTORY}

Received 22 December 2016 Accepted 6 April 2017

\section{KEYWORDS}

Racism; discourse; logics; interpretive repertoires; interpretive functionalism; articulation

\section{Introduction: the controversy about racism's relativity in Flanders}

This paper offers an interpretive and functional discourse analysis of the meanings informing a Flemish nationalist discourse that brands racism as [a] relative [concept], based on the concept of discourse as an articulatory practice. On 17 August 2013, Liesbeth Homans, a politician of the New Flemish Alliance (N-VA) stated:

Racism is a relative concept. I deplore that the word is used so quickly today. Is there still racism? Probably yes. On the part of the autochthon population with respect to the allochthon population? Probably yes. The other way around? That too. But today, racism is mostly used as an excuse for personal failure. (Homans quoted in Homans and De Ridder 2013)

Later on Homans remarked repeatedly that these statements 'continue to haunt' her but that she nevertheless continues to stand by what she said (Homans cited in Carton 2013; Homans 2014b, 2014a, 2016). Her statements were criticized from the outset, but ironically, the massive amount of critique helped them to go viral in Flanders. Asserting 
racism's relativity would even become a hallmark of the N-VA. This paper analyses the way $\mathrm{N}$-VA politicians articulate their understanding of racism in relation to racism-related interpretive repertoires and logics circulating in Flanders and in Europe.

Racism-is-relative discourse delegitimizes anti-racist notions of racism such as structural racism, racism as an ideology, entitlement racism or racism as white privilege. It serves as a shield against accusations of racism. It is integrated with the repertoire of new realism and with neoliberal and culturalist logics. Since multiculturalism, diversity and anti-racism are the objects of right-wing populist critique across Western countries (Aalberg et al. 2017; Moffitt 2016; Vertovec and Wessendorf 2010b; Yilmaz 2012), it is important that cultural discourse studies pay close attention to the way the category of racism is being re-articulated by West-centrist forces that proclaim the superiority of a supposedly homogeneous Western culture (Shi-xu 2016, 1).

I will start out with some contextual information regarding discourse on race, racism and its denial in Europe and in Flanders specifically. I will then move on to discuss the notion of articulation and my interpretive and functional heuristic for discourse analysis. The research results detail how assertions of racism's relativity are embedded in a discourse that draws on the interpretive repertoire of new realism. This discourse undermines scientific and activist concepts of racism. Through an analysis of the way racism-is-relative discourse is articulated with(in) culturalist and neoliberal logics, I will show how racism is being delegitimized as a valid object of emancipatory politics and policy.

\section{Racism and its denial: international and local tendencies}

From a superficial semiotic and discourse analytical point of view, N-VA chairman and mayor of Antwerp Bart De Wever is right when he says that 'all isms are relative, and so is racism' (De Wever 2015). However, this assertion is anything but a postmodern assertion about the relative fixation meaning (Zienkowski 2017, 51-82). It is part of a nationalist project that combines traditional culturalist and neoliberal principles in an attempt to de-politicize non-biological understandings of racism.

Denials and mitigations of racism are not new in Flanders or in Europe (Blommaert and Verschueren 1998; Van Dijk 1992). In fact, racism has become such a face-threatening accusation after WWII that accusations of racism are often considered to be more serious social infractions than racist acts and statements themselves. Denials of racism play a crucial role in the positive self-representation of individuals, groups and societies in Europe. Four common types of denial include (Van Dijk 1992, 92):

(1) Act-denial (e.g. I did not do/say that at all)

(2) Control-denial (e.g. I did not do/say that on purpose; It was an accident)

(3) Intention denial (e.g. I did not mean that/You got me wrong)

(4) Goal-denial (e.g. I did not do/say that in order to)

Racism is often denied when defined as discrimination on the basis of biological characteristics or associated with Nazi-like ideological practices (Hesters 2011, 55). Discrimination on the basis of cultural, ethnic or religious features and practices is rarely considered to be racist in right-wing discourse in spite of the fact that culturalist conceptualizations of 
identity operate on the basis of similar exclusionary principles as the biological concept of race (Augoustinos and Every 2007; Lentin 2014).

In Flanders and in much of Western and Northern Europe, even the far right tends to distance itself from the category of race and prefers to talk about backward cultures and the defence of European or so-called Judeo-Christian norms and values in the face of an Islamic threat (Maly 2007b, 102). Euphemisms such as discrimination or stereotyping play a particularly important role in contexts where talk about race and racism is considered to be taboo and needs to be mitigated. At times, racism is even justified as a legitimate response to the problematic behaviour of others. Such justifications often lead to a tactic of blaming the victim or to a tactic of reversal (e.g. it is not we who are racist, it is them who choose not to integrate themselves because they are the real racists) (Van Dijk 1992, 92-94).

As we will see, the assertion that racism is [a] relative [concept] relies on a combined strategy of denial, mitigation and justification. The discourse of the N-VA exemplifies a relatively sophisticated type of anti-anti-racism in Europe. Contemporary racism frequently presents itself as an acceptable mode of - banal - nationalism. It claims not to think in terms of race and states that it merely seeks to address backward - usually Islamic belief systems and practices that are considered to be antagonistic to the Enlightenment values that supposedly unify post-racial national and/or European projects (Lentin 2014; Moffitt 2016; Vertovec and Wessendorf 2010b; Yilmaz 2012).

Culturalism is a common denominator for virtually all right-wing populist projects in Europe but can be found across the entire political spectrum of most European nationstates. It is not the monopoly of the radical right and has grave implications for the status accorded to (accusations of) racism (Lentin 2014; Sakki and Pettersson 2016):

The seriousness of the charge of racism coupled with the common-sense understanding that it refers exclusively to skin colour mean that all other bases for discrimination can be seen as being relative to it. [ ... ] Cultures are incompatible; races, at least officially, do not exist. Hence neither does racism. (Lentin 2014, 7)

Due to the force with which experiences of racism by minority members are being dismissed by the right and due to the idealist liberal self-image of a post-racial society in which race has become irrelevant, anti-racists and victims of racism are bereft of a vocabulary for critique. It is therefore key to distinguish between anti-racialism (the opposition to the concept of race) and anti-racism (the opposition to the conditions and experience of racism). Anti-racialism does not necessarily imply anti-racism (Lentin 2014, 9). The N-VA discourse about racism's relativity is a case in point.

It is useful to consider how the N-VA positions itself in relation to the radical right VB (Flemish Interest). The VB denies that it is racist while it rails against multiculturalism, against the 'Islamification' of Flanders and Europe, and against politically correct elite that is blind to the 'real problems' of 'the people'. It has put the issue of integration on the mainstream political agenda in the eighties and kept it there, in spite of a cordon sanitaire(Coffé and Dewulf 2014) that was put into place in order to bar this party from partaking in policy (De Cleen and Carpentier 2010). The N-VA climbed to power rapidly and is now the biggest political formation in Flanders. It is also the dominant party of the federal Belgian government since 2015 when it won the elections with an anti-socialist, neoliberal, and conservative campaign. The N-VA positions itself as a realistic alternative 
to the VB by arguing for a 'good' mode of civic nationalism that opposes the 'bad' ethnic nationalism of the VB (Maly 2012, 2016).

Proponents of N-VA style civic nationalism claim that as long as immigrants and their descendants subscribe to a supposedly homogeneous and shared set of values, anyone - including non-radical or non-extremist Muslims - can become part of an 'open', 'organic', and 'ethical community' (Maly 2016, 266, 270-271). A homogeneous Flemish nation is nevertheless the community that sets these values. The N-VA rejects the racism of the VB and publicly denounces VB politicians who claim that Flanders has become 'too brown' (Jta 2014). Nevertheless, a big part of its electorate used to vote for the VB and many of its politicians used to be active in this party (Coffé and Dewulf 2014, 159-161).

There is no unified definition of racism in the field of discourse analysis in spite (or because of) the vast amount of literature on race (e.g. Back and Solomos 2000; Blommaert and Verschueren 1998; Reisigl and Wodak 2001; Van Dijk 2000; Wetherell and Potter 1992; Wodak 2009). Nevertheless, racism always implies discriminatory and excluding discursive practices and it is always articulated with discursive elements taken from other ideological projects such as nationalism, sexism, or culturalism (Miles 1993 cited in Reisigl and Wodak 2001 , 9). The meanings of the signifier racism therefore shift along with the elements with which it is articulated (Laclau and Mouffe 1985). Racism fixes social and political relationships in unequal and hierarchic configurations through exclusionary and discriminating logics that take historically specific forms.

Concepts and experiences of racism also come in many forms (Reisigl and Wodak 2001; Romm 2010). Not all of these forms enjoy equal status in the public realm. Academic or anti-racist notions of racism are not always known or accepted outside of these circles. For instance, concepts such as entitlement racism (Essed and Hoving 2014), cultural racism, new racism (Balibar 1991; Romm 2010), or racism as white privilege (Rothenberg 2015) are practically absent in the non-academic sections of the Flemish public sphere. A noticeable exception is the notion of everyday racism (Essed 2001) that was actively promoted by activists and victims of racism active on social media in response to N-VA discourse on racism's relativity.

\section{An interpretive and functional approach to discourse on racism's relativity}

In the upcoming analysis I rely on an interpretive and functional heuristic based on the poststructuralist concept of articulation (Glynos and Howarth 2007; Howarth 2005; Laclau and Mouffe 1985). Interpretive functionalism is a heuristic designed to investigate functional relations between semiotic forms, the practice(s) in which they are embedded and the metadiscursive positioning of interlocutors in discursive networks (Zienkowski $2017,403)$. Saying that racism is [a] relative [concept] implies more than making a declarative statement about the meaning of racism. This assertion allows its author and/or enunciator to articulate himself/herself within a wider debate, to claim particular identities, and to link up with historically and locally grounded discourse on racism.

My data are mostly textual but I subscribe to the idea that discourse cannot be reduced to language use alone. Discourse is a multi-layered, context-dependent and socially constitutive practice of articulation - both in the sense of a linkage of linguistic and non-linguistic discursive elements and in the sense of a performance. It may include verbal and/or 
textual language use, but also multimodal data and ethnographic observations. Discourse is organized at multiple levels of linguistic, textual, semiotic and/or socio-political organization. Like Foucault, I will allow the boundaries of what is meant by discourse to shift and change because its basic elements are defined by function rather than form (Foucault 1969, 98; Zienkowski 2017, 96).

Below, I will use my interpretive and functional heuristic in order to investigate how assertions of racism being [a] relative [concept] have been articulated with: implicit and explicit definitions of racism; discursive elements of widespread interpretive repertoires; and the political logics that shape the hegemonic project of the N-VA (Glynos and Howarth 2007; Wetherell and Potter 1988; Wetherell 1998). Articulation can be defined as follows:

Articulations of statements, signifiers, identities, narratives and/or political identities rely upon linguistic and/or non-linguistic performances that render them material. The practice of articulation allows for reflexive modes of subjectivity. The associated performances establish pragmatic boundaries for (self-) interpretation and temporarily fix discursive forms onto interpretive functions. Any articulation of two or more discursive elements alters the meaning of the elements involved. (Zienkowski 2017, 399)

I collected all articles matching the query 'racism AND relative' in the Dutch GoPress database for news articles. I then manually selected all articles containing (discussions of) assertions of racism being [a] relative [concept] published between 14 August 2013 when Homans coined this idea and 27 April 2015 (the day of the search). My approach is interpretive. It allows me to analyse N-VA discourse on racism as a metadiscourse (a discourse about discourse) marked by a high degree of reflexivity that draws on the interpretive repertoire of new realism. It is functional because it stresses that any rearticulation of the signifier racism into new discursive patterns involves changes of meaning.

My corpus contains 81 articles from the outlets Belga; De Morgen; De Standaard; De Tijd; GvA; Het Laatste Nieuws; Het Nieuwsblad; Humo; 't Pallieterke; Trends; Mo* and Knack. I also added all articles that matched the expression 'racisme is relatief' (English: racism is relative) on the website of the VRT (the Flemish public broadcasting company), the website of the online left-wing news channel DeWereldMorgen, and the website of the anti-racist organization Kif Kif. Moreover, I included six articles indispensable for the analysis of specific episodes of the debate and a transcription of a TV interview with Bart De Wever.

All data were imported into the CAQDAS program NVIVO for Mac. I coded all voices articulating statements on racism, the implicit and explicit definitions involved, as well as the modes of critique these voices engaged in. This coding process was a preliminary step facilitating the identification of relevant elements for answering the following interpretive and functional research questions:

- What functions do assertions of racism as [a] relative [concept] perform in relation to implicit and explicit definitions of racism used in the immediate textual context of this assertion?

- What functions do such assertions perform in relation to interpretive repertoires and logics informing widespread discourse about culture, race, and diversity in Flanders?

- What functions do assertions of racism's relativity perform in relation to the political project of the N-VA? 
In answering these questions, I will show how assertions of racism's relativity have been articulated with elements from the interpretive repertoire of new realism (Prins 2002; Prins and Saharso 2010; Wetherell 1998; Wetherell and Potter 1988) and with the culturalist and neoliberal logics that inform the N-VA's populist political strategy (Glynos and Howarth 2007). An interpretive repertoire is 'a culturally familiar and habitual line of argument comprised from recognisable themes, common places and tropes (doxa)' (Wetherell 1998). Logics are interpretive patterns that configure the way subject positions, statements, narratives, practices, and institutions can be articulated with each other in particular socio-historical contexts (Howarth 2005; Zienkowski 2017, 404).

My corpus contains 173 coded re-articulations of Homans' voice in 54 articles. Bart De Wever's voice is coded 127 times in 30 sources. De Wever authored none of these sources and only appears once as an interviewee in a manually added transcription of a televised debate. The voices of Homans and De Wever are nevertheless omnipresent in the form of direct and indirect reported speech.

In this article, I will focus on articles authored by Homans and on interviews conducted with Homans and De Wever. In a follow-up article, I will discuss the way their voices have been re-articulated and criticized by other actors in the debate. All excerpts presented below come from sources that contain at least one explicit assertion of racism being [a] relative [concept]. The excerpts do not always contain explicit talk on racism's relativity but do provide the necessary context for understanding the meaning of this assertion.

\section{Discursive patterns informing the assertion of racism's relativity}

Homans and De Wever tap into patterns that have defined debates on multiculturalism and racism in Flanders for decades. Their racism-is-relative discourse draws on an interpretive repertoire called new realism that informs a type of smug ignorance about racism. The resulting discourse is reinforced by neoliberal and culturalist logics that inform the N-VA's Flemish nationalist project.

The discourse surrounding assertions of racism's relativity has been coded for implicit and explicit definitions of racism used by N-VA politicians. The most common codes are obviously racism as relative and racism as a relative concept. Next we see racism as an excuse for personal failure, as a reality and as a consequence of migration or languagerelated problems. Racism also appears as a problem of those who do not take the chances offered to them and as an unjust accusation. Many coded segments refer to definitions of racism as a consequence of misunderstandings, talk about racism, criminality, multicultural apartheid, Islamic radicalism or salafism, socio-economic problems in particular communities, negative experiences and perceptions and/or as a consequence of underspecified set of problems.

$\mathrm{N}-\mathrm{VA}$ voices only discuss racism as a political phenomenon when they discuss racism defined as manifest discrimination of the biological variety (De Wever 2015). De Wever and Homans use this narrow definition of racism in order to position their party as a moderate right-wing alternative to the radical right VB. Undeniable discrimination on the basis of skin colour or descent is the only form of racism that is deemed to fall within the action radius of party politics. However, when Homans denounces 'pure racism' or 'racism in the open', she also stresses that politicians do not have the power to make racism disappear (Homans 2014a). 
In some cases, N-VA politicians seem to understand racism as a cause for Islamic radicalization. This would be a decidedly political effect of racism. For instance, during a mediatized debate on Islamic radicalization, N-VA chairman Bart De Wever acknowledged a link between racism and discrimination. Many commentators mistook this statement as meaning that the N-VA now recognized that Flemish racism was an explanative or causal factor for Islamic radicalization. De Wever rightly pointed out that these commentators 'did not get it at all' (De Wever 2015).

Social scientific concepts of racism do not enter the picture. In fact, conceptual discussions on racism are a rarity in Flemish mainstream media. Theoretically informed notions of racism can almost exclusively be found on online left-wing media.

\section{Racism's relativity as part of new realist discourse on multiculturalism}

By tapping into the interpretive repertoire of new realism, the N-VA positions itself as the vox populus of a homogenous population that struggles to overcome the delusional multicultural ideas of politically correct left-wing and/or traditional elites. Prins describes new realism as a genre of discourse containing a set of discursive tropes that characterize right-wing populist discourse in Flanders and in the Netherlands (De Cleen 2006; Maly 2009; Prins 2002). I will discuss new realism in terms of an interpretive repertoire (Wetherell 1998).

Interpretive repertoires contain 'building blocks speakers use for constructing versions of actions, cognitive processes and other phenomena' (Wetherell and Potter $1988,172)$. They consist of 'a restricted range of terms used in a specific stylistic and grammatical fashion' (Wetherell and Potter 1988, 172). They may contain metaphors, figures of speech and other tropes and can be used as a platform from which 'accusations and justifications can be launched' (Wetherell 1998) to the overall effect of creating a 'morally virtuous self-representation' (Wetherell and Potter 1988, 182). Moral accusations of political correctness are key to understanding new realism and the way assertions of racism's relativity tap into pre-established patterns for talking about multiculturalism.

New realism is part of the multiculturalism backlash, a discourse that considers multiculturalism to be a perverse consequence of welfare policies that supposedly allowed specific ethnic, cultural, and religious minorities to create parallel, separate, segregated lives and that supposedly bread radicalism, extremism, and even terrorism (Vertovec and Wessendorf 2010a, 12-13). New realism consists of four tropes. It informs a warped but highly reflexive metadiscourse about real or imagined discursive norms, values, and practices associated with multiculturalism (Prins 2002; Prins and Saharso 2010; Verschueren 2011):

[A new realist is] someone who dares face the facts, who speaks frankly about 'truths' that the dominant discourse has supposedly covered up. [...] Second, a new realist sets himself up as the spokesperson of the ordinary people, that is, the autochthonous population. [...] A third characteristic of new realism is the suggestion that realism is a characteristic feature of a Dutch identity: being Dutch equals being frank, straightforward and realistic. A fourth and final feature of new realism is its resistance to the left. New realists find it is high time to break the power of the progressive elite that dominates the public realm with its politically correct sensibilities regarding fascism, racism and intolerance. (Prins 2002, 368-369) 
New realism is a folk realism that has nothing to do with philosophical realism. Its adherents claim to see things as they really are as opposed to a multicultural elite that is blinded by its own ideals. Populists across Europe and beyond use this repertoire in order to attack 'politically correct' opponents. New realism has an important performative dimension. In order to perform new realism, one has to engage in hard-talk that problematizes migrants and their offspring harshly and without compromise.

In its toughest forms, empathy and politeness are emphatically thrown overboard regarding immigrants and/or their descendants. Softer varieties of new realism combine an explicit recognition of the need to articulate hard truths with a call for dialogue. The tough variety is marked by an elevation of freedom of speech as the highest value of democratic nation-states. It posits that the time of (intercultural) dialogue is over and that a dominant culture has the right to dictate a set of non-negotiable norms to its minorities (Prins and Saharso 2010).

As new realist statements become tougher we move towards a mode of political communication that can be labelled as post-truth politics. Prins calls this phenomenon hyperrealism (Prins 2002, 374-375; Prins and Saharso 2010, 78). Hyperrealism is primarily a performance of frankness, a venting of feelings, not for the sake of truth, but for its own sake in a public performance of populist leadership. Both new realism and hyperrealism value freedom of speech over the right not to be discriminated against (Prins 2002, 374-375; Prins and Saharso 2010, 78). Van Gogh's film Submisson and Wilder's film Fitna are examples of hyperrealism. Other examples include descriptions of Islam as a 'disease' or mainstream political talk about so-called cunt-Moroccans (Dutch: kutmarokkanen). Hyperrealism constitutes a form of entitlement racism. Essed and Hoving define entitlement racism as a discourse that narrows freedom of speech down to the right to offend. According to them,

[...] the right of freedom of speech has won over the right of protection against discrimination; antidiscrimination and antiracism are off the political agenda; references to the need for tolerance, no matter how contested the principle, have disappeared [ ... ]. (Essed and Hoving 2014, 11)

Dutch right-wing populist politicians such as Geert Wilders have successfully developed and normalized hyperrealist discourses about multiculturalism (Prins and Saharso 2010, 84). In Flanders, hyperrealism and entitlement racism are more characteristic of the VB than of the N-VA. Nevertheless, N-VA's assertions of racism being [a] relative [concept] do tap into the tough variety of new realism. In Flanders political correctness has effectively become a curse word (De Cleen 2006, 92; Jacobs and Rummens 2003; Lentin 2014; Maly 2009).

The call 'to break taboos' used to be a hallmark of the VB but now informs hegemonic discourse on integration (Blommaert 2005; Blommaert and Verschueren 1998, 190, 201202). The repertoire of new realism has been picked up not only by right-wing voters, but also by socialist politicians and media figures who agree that one has 'to name the problems' and 'to call a spade a spade' in talk about Islam, multiculturalism and/or (super) diversity (De Cleen 2006; Jacobs and Rummens 2003; Maly 2009, 164-170). Homans initial assertion of racism as a relative concept is immediately preceded by a textbook example of new realism: 
You have to name the problems by their name. Not pretending as if everything is peace and happiness - that's hypocritical. Migration certainly has benefits. But also drawbacks. I really don't go along with this eternal happy story about diversity having brought only good things any longer. The mainstream Antwerp person does not believe in it anymore. And least of all myself. (Homans quoted in Homans and De Ridder 2013)

In the above quote Homans presents herself as someone who dares to face the facts and speaks truths about the - supposedly dominant - discourse on diversity in Flanders; she sets herself up as the spokesperson of the average Flemish who - supposedly - does not delude him/herself about diversity either; she weaves this type of realism into a claim on Antwerp/Flemish identity; and she distances herself from a so-called happy story about diversity and racism articulated by a left-wing elite.

\section{Asserting racism's relativity in order to ignore scientific and critical concepts of racism}

Denials, mitigations, and/or justifications of racism are often part of a performance of smug ignorance about the social realities faced by those who experience daily racism and about the socio-historical contexts that inform discriminatory practices and structures. The assertion of racism being [a] relative [concept] is part of such a performance.

Smug ignorance is a purposeful ignorance of the way discourses of cultural progress and racialized understanding of civilization that humanize some and de-humanize others inform each other. This ignorance goes hand in hand with a general 'sense of self-satisfaction and smugness about ignoring the issue. Racism is thereby seen as an out-dated topic that has no relevance in the twenty-first century' (Augoustinos and Every 2007; Essed and Hoving 2014; Van Dijk 1992).

Smug ignorance and denials of racism can be observed in the repetitive annual debates on the allegedly racist character of the folkloristic black-faced figure of Black Pete (van der Pijl and Goulordava 2014; Zienkowski 2016); the scarcity of public discussions on the Dutch involvement in slavery and the slave-trade (Nimako et al., 2014); the limited, chaotic, and partial attention for the excesses of Belgium's colonial past and relationships with Congo (Arnaut et al. 2009); and an overall refusal to critically examine the phenomenon of racism as being about more than discrimination on the basis of skin colour and descent by isolated individuals.

Smug ignorance is also present in the discourse of Liesbeth Homans who fixes the meaning of racism as an unjust accusation, as an exaggeration, as an excuse for personal failure, as a politically correct term, and as a label that - when used at all - should be restricted to describe discriminatory practices based on skin colour or descent or to understandable but exceptional reactions of people grieved by multicultural realities. As such, racism is frequently justified as a natural reaction to a presupposed lack of individual responsibility demonstrated by minority members in areas such as the labour market or in everyday interactions in the public realm. Consider the following quote:

My two children play basket, both in teams that are made up halfway of allochthons. Those clubs operate completely on the basis of volunteers: mums and dads that do the bar, who wash t-shirts and whistle. We are with ten people and it's always the same five people who have to do all the work. 'You never see Ömer's mom here' is what you hear then. So you need to walk up to Ömer's parents and do your very best to explain that it is common practice 
to tap some beers once in a while. And if this is sensitive, take care of coffee and tea then. Is this racism? No, it is a two-way lack of understanding. (Homans quoted in Homans and De Ridder 2013)

The excerpt above reduces the meaning of racism to an unjust accusation in a context marked by a mutual lack of understanding. Throughout the debate Homans repeatedly refers to possibly fictive allochthon youngsters who are told that that they should take their feet of the seat of a public tram and who react with unjust accusations of racism (Carton 2013; Homans and De Ridder 2013). Racism thus becomes a slur that is invoked whenever majority members voice well-meant normative concerns about minority members' problematic attitudes and actions. This reduction allows Homans to bypass social scientific notions of racism and to support the idea that racism is relative.

Yes, there is still a basis for racism. But way less than we think our-selves. The more we talk about racism, the more we feed it. (Homans quoted in Homans and De Ridder 2013)

Homans understands racism as a logical reaction to underlying issues. The notion of a 'basis for racism' suggests that racism is not a problem in itself but an epiphenomenon whose root causes lie elsewhere. She explains racism with reference to 'failures' of minority members. Unjust accusations of racism that compensate for the lack of success scored by so-called allochthons aggravate the problem in her eyes. Racism-is-relative discourse disarticulates racism from the criminal domain and has severe depoliticizing effects. When asked whether she has ever witnessed racism in her own life, Homans responds with indignation:

A 'witness to racism'? You act as if it is an abomination, a crime against humanity. The Fleming is sometimes so ashamed about his own language or culture. If you hear other parties about a course for learning Dutch, it almost seems as if it is a corporal punishment. 'Learning Dutch?' 'Fool.' 'You dirty fascist'. (Homans quoted in Homans and De Ridder 2013)

The accusation of racism is treated as a slur that can be used whenever majority members make normative claims regarding Flemish language and culture. Homans justifies potential racist acts as normal performances of cultural and/or linguistic pride in a public performance of smug ignorance about academic and anti-racist understandings of racism.

Supporters of exclusionary rhetoric in the Netherlands present themselves as victims rather than as aggressors. They claim to be merely defending what is theirs and 'will not accept being called racist because they consider themselves to be people who are of good will and intention' (Ghorashi 2014, 112). This idea can also be found in N-VA discourse. When Homans first asserted racism's relativity, the journalist interviewing her pointed out that 'Mohamed' finds it generally more difficult to rent a house in Flanders then 'Sven' or 'Liesbeth'. Homans' response contains all of the tropes discussed above:

I am not saying that we cannot speak about the discrimination of allochthons anymore. But above all, we should not exaggerate. Let us call a spade a spade. There is still a small group of allochthons that ruins it for the entire community. Do we need to pretend that Mohamed who steals a wallet on tram 12 is the biggest criminal in the world? No. But pretending as if nothing is going on in Antwerp, that's just hypocritical. (Homans quoted in Homans and De Ridder 2013)

Racism and discrimination should be discussed exclusively in new realist terms. By keeping its distance from the hyperrealist variety of new realism, N-VA politicians 
distance themselves from the rancid language of the VB. Nevertheless, critical and social scientific notions of racism do not enter the picture at any point, leaving no room for debate, facilitating denials, mitigations, and justifications of most forms of contemporary racism.

\section{Culturalist and neoliberal logics informing populist claims on racism's relativity}

$\mathrm{N}$-VA style new realism works in tandem with neoliberal and culturalist logics deployed in a populist strategy that opposes a Flemish identity to a politically correct elite. The notion of logic is borrowed from poststructuralist discourse theory and refers to the interpretive patterns that configure relationships between subject positions, statements, narratives, practices, and institutions (Glynos and Howarth 2007; Zienkowski 2017, 404).

The neoliberal logic informing N-VA politics shows not only in its austerity politics but also in its approach to racism. Politicians such as Homans and De Wever refuse to acknowledge racism as an explanative factor for discrimination. When De Wever stated that 'all isms' including racism 'are relative' (De Wever 2015), he also said that:

I think one can only address racism structurally by realizing social-economic progress among those population groups, it is not merely a battle against racism eh, this is a general societal task that has to be taken up. (De Wever cited in De Wever 2015)

At first sight, the above quote seems to suggest that De Wever does allow for structural racism as a valid analytical term but this would only be true in a very limited sense. He does not refer to structural racism as a concept that describes 'the role of racist power structures in the generation and reproduction of racialized division' (Romm 2010). On the contrary:

If she [Homans] says that racism is relative, I understand very well what she means. It is very easily used as an excuse for personal failure. (De Wever cited in De Wever 2015)

For De Wever, racism can only be dealt with by 'activating' allochthons in the labour market through neoliberal reforms that force them out of the safety net of social security. In his view, this net has been misused as a 'hammock' by allochthons and Walloons who refuse to take the chances offered to them. The image of the ungrateful other looms around the corner (Ghorashi 2014). Social factors that fall outside of the realm of individual control and responsibility have no place in the neoliberal logic of the N-VA. The only structural reforms its politicians are willing to consider are policies of austerity, activation, and individual responsibility.

Racism-is-relative discourse also works in tandem with a widespread culturalist logic that problematizes Islam as an explanative factor for social problems. In Flanders, this logic informs the opposition between so-called allochthons and autochthons, as well as practices of othering in general (Maly 2007a; Zienkowski 2014). In a televised interview, De Wever justified racism as a deplorable but understandable response of citizens facing problems with specific ethnic, cultural and religious communities, placing the responsibility for racism with these minorities themselves. For him, racism is a 'wrong response of the population', but also

a consequence of many negative perceptions and experiences, fair or unfair that make you turn towards a culture of distrust that can be translated into a very negative attitude 
towards migrants. Especially [towards] people of North-African descent. Especially [towards] Moroccans. Especially [towards] Berber Moroccans, of which there are a lot in Antwerp. (De Wever cited in De Wever 2015)

$\mathrm{N}$-VA politicians only describe racism as real when considering it in the narrow sense as being about skin colour, or when they explain the phenomenon as a logical consequence of: the 'multicultural' segregation of closed communities that do not mingle with the Flemish mainstream; attitudinal issues of (groups of) allochthons with respect to work, welfare, women, religion, and the government; and international terrorism.

Whatever the reasons for people to turn racist, racism is not granted a dynamic of its own. It does not operate as an ideology that informs segregation, discrimination, and exclusion but operates as a mere consequence of problems that should be addressed through neoliberal reform. Consequently, racism appears as an unavoidable problem that suddenly becomes surprisingly real:

Of course, racism exists and this is very regrettable. It has always existed, it still exists and since 9/11 we didn't get a happier world as far as that is concerned either. So, the distrust between the Muslim world and the Western world has grown and this translates into our big cities all across Europe. This apartheid that was already there in fact, there is very little contact, very little marriages among communities, this in itself is a problem that racism feeds upon. I'm not the only one saying this. (De Wever 2015)

According to De Wever, people of Berber and Moroccan descent live in 'very closed communities with distrust towards the government, a weakly organized Islam, very prone to the salafist current and therefore also to radicalization'. The 'decapitations' of IS in Syria and 'people sympathizing with that' are seen as causes of racism and rejection. According to De Wever, racism has a basis in a reality where people travel to Syria to join IS and where people 'are named allochthons' and 'still call themselves allochthons' after four generations (De Wever 2015). Ignoring the refusal of his party to do away with the binary pair of allochthony/autochthony, he blames people of Moroccan descent for this problematic terminology that was developed by policy makers and scientists to objectify them in the first place (Jacobs and Rea 2006; van der Haar and Yanow 2013; Zienkowski 2014).

The idea of racism as an unjust accusation pops up once again when De Wever makes a culturalist hierarchy of ethnic groups that supposedly deal with (accusations of) racism in different ways:

I am absolutely not going to deny that it [racism] exists eh. It exists everywhere and this is regrettable. But there are also other problems eh. For instance, I have never met an Asian migrant in Antwerp who said 'I am a victim of racism'. I have (.) I don't see them popping up in the crime statistics either, nevertheless there are thousands. (De Wever 2015)

The above statement on the Antwerp Asian community was immediately repudiated with a Twitter and Facebook storm of accounts of everyday racism posted by people of Asian descent.

\section{Depoliticizing racism by claiming racism's relativity}

The depoliticizing effect of racism-is-relative discourse fits well with the party's neoliberal TINA (There Is No Alternative) mantra. Remember that the only proper way to tackle the underlying causes of racism lies in strategies of cultural integration or assimilation, or in 
neoliberal reforms. TINA informs the N-VA's depoliticizing approach to racism. As De Wever put it, 'Politics cannot solve everything. Society is only malleable to a limited extent' (De Wever 2015). Homans first introduced this depoliticizing approach to racism half a year earlier. In a response to an open letter in which activist sociologist Samira Azabar addressed problems of everyday racism in Antwerp (Azabar 2014), the former articulated the view that politics can have virtually no impact on the phenomenon of racism:

I have to disappoint you, Samira. And with me the entire political world will have to do that as well. There is no law in the world that can make racism go away. It was there when you still felt 'the city was yours' and it is still there today. (Homans 2014b)

Homans continued and described racism metaphorically as a 'slow poison we get all exposed to and that some are not equipped to handle'. The most politics can do, is 'to limit the dosage' by engaging in a politics of new realism: 'not by singing the praises of multicultural society and being blind for problems but by naming those problems and tackling them at their roots'. According to Homans, these roots are language-related problems that impact on school trajectories and labour market integration. Politics can merely 'take away the humus of racism' (Homans 2014b) by engaging in a new realist discourse and by developing a policy consistent with the party's neoliberal and culturalist logics:

It is the obligation of politics to offer chances and second chances, but people have the duty to take these chances with both hands and to ensure themselves a better life. This is the only way to root out racism at its base and to take away its arguments. (Homans 2014b)

Assertions of racism's relativity link up with nationalist concerns, with neoliberal views on subjectivity and with a view on racism as an understandable and realistic response to the realities that characterize our times.

\section{Conclusion}

The overall function of asserting racism's relativity is to reserve the signifier of racism for explicitly observable discriminations of people on the basis of race and/or descent and for the discourse of the Flemish nationalist VB. It delegitimizes the interpretive repertoire of progressive intellectuals, social scientists, and activists who talk about structural racism, racism as ideology, entitlement racism, or racism as white privilege.

Articulations of racism's relativity by N-VA politicians tap into established discursive patterns such as the interpretive repertoire of new realism. Those who hold that racism is [a] relative [concept] oppose themselves to minorities and politically correct elites who see racism everywhere. The idea that racism is [a] relative [concept] acts as a shield against accusations of racism and supports the idea that racism should not be a political issue. The only actors who can be held responsible for racism are those who complain about it. A key function of articulating racism's relativity is to project a positive self-image of Flemish identity while suggesting that anyone who talks about such issues is doing so because of an unpatriotic sort of self-loathing. Assertions of racism's relativity can only function in this way because other understandings of racism can be excluded from consideration.

The idea that racism is [a] relative [concept] also reinforces the populist metadiscourse of new realism and reproduces the neoliberal and culturalist logics that inform the N-VA's 
political rationality. By relativizing racism the $\mathrm{N}$-VA provides a positive self-image for Flemish nationalists, as well as a justification for neoliberal reforms on the labour market and for targeting specific minorities in law-an-order policy. The combined effect is a double-edged understanding of racism.

The N-VA politicizes racism as an unjust accusation aimed at well-meaning Flemish by politically correct elites and minorities, but also depoliticizes it as a responsibility of those in power. Since racism is a deplorable but natural consequence of transgressions committed by minority members that are unwilling to take the opportunities offered to them, it becomes the sole responsibility of those who feel like they are discriminated against. We are dealing with an elaborate discursive construction that effectively blames potential victims of racism for being discriminated against. It is a form of anti-racialism that is anti-anti-racist.

Relativizing racism is an effective strategy for dodging political responsibility regarding discrimination on the labour market, the real estate sector and other domains where racism has proven to inform discriminatory practices. It also allows the N-VA to distinguish itself from the blatantly racist $\mathrm{VB}$. If racism is relative, this does not imply that racism does not exist. It does make all interpretations of certain discourses and practices as marked or informed by racism suspect and robs accusations of racism of their performative power. Racism is not credited with any ideological force of its own.

The relevance of racism-is-relative discourse exceeds the Flemish context. The discursive patterns it taps into can be found in populist discourses across Europe and beyond. The idea that racism is relative may not be applied as easily in every context, but it does provide an effective defence against accusations of racism in contexts marked by low degrees of political awareness regarding racism's many faces. This being said, it should be stressed that I do not wish to suggest that the N-VA's notion of racism was left unchallenged. In order to fully understand the debate it is also important to investigate how N-VA assertions of racism's relativity have been re-articulated by critics and opponents in the ensuing debate. This critical reception will be the focal point of a follow-up article.

\section{Acknowledgements}

Special thanks should go to my friend and colleague Dr Daniel Moulin-Stożek for his valuable feedback on this paper.

\section{Disclosure statement}

No potential conflict of interest was reported by the author.

\section{Funding}

This work has been supported by MINECO (Ministry is Ministerio de Economía, Industria y Competitividad).

\section{Notes on contributor}

Jan Zienkowski works as a post-doctoral researcher at the Institute for Culture and Society (ICS) at the University of Navarra (UNAV) in Pamplona, Spain. He is author of Articulations of self and politics in activist discourse (Palgrave Macmillan, 2017). Jan's research focuses on subjectivity, reflexivity, and 
critique as articulated in large-scale political debates on migration, populism, and neoliberalism. He aims to rearticulate linguistic pragmatic, critical, and poststructuralist approaches to discourse in an endeavour to understand the way human beings deal with hegemony with varying degrees of awareness.

\section{References}

Aalberg, T., F. Esser, C. Reinemann, et al. 2017. Populist political communication in Europe. New York: Routledge.

Arnaut, K., S. Bracke, B. Ceuppens, S. De Mul, N. Fadil, and M. Kanmaz. 2009. Het gekooide Vlaanderen: twintig jaar gemist multicultureel debat. In Een leeuw in een kooi: de grenzen van het muliticulturele Vlaanderen, eds. K. Arnaut, S. Bracke, B. Ceuppens, S. De Mul, N. Fadil, and M. Kanmaz, 7-25. Antwerp: Manteau.

Augoustinos, M., and D. Every. 2007. The language of "race" and prejudice: A discourse of denial, reason, and liberal-practical politics. Journal of Language and Social Psychology 26: 123-141.

Azabar, S. 2014. Antwerpen, ik hou van u, ik walg van u. http://www.kifkif.be/actua/antwerpen-ikhou-van-u-ik-walg-van-u (accessed 09/06/2015).

Back, L., and J. Solomos. 2000. Theories of race and racism: A reader. New York: Routledge.

Balibar, E. 1991. Is there a neo-racism? In Race, nation, class: Ambiguous identities, eds. E. Balibar and I. Wallerstein, 17-28. London: Verso.

Blommaert, J. 2005. Discourse. Cambridge: Cambridge Univ. Press.

Blommaert, J., and J. Verschueren. 1998. Debating diversity: Analysing the discourse of tolerance. London: Routledge.

Carton, W. 2013. Racisme is relatief, daar blijf ik achter staan. De Redactie, December 1.

Coffé, H., and J. Dewulf. 2014. Wavering between radical and moderate: The discourse of the Vlaams Belang in Flanders. In Doublespeak: The rhetoric of the Far Right since 1945, eds. M. Feldman and P. Jackson, 147-166. Stuttgart: Ibidem Verlag.

De Cleen, B. 2006. Multiculturalism and 'saying it like it is': Mapping discourses of political correctness in North Belgium. In Researching media, democracy and participation, eds. N. Carpentier, P. Pruulmann-Vengerfeldt, K. Nordenstreng, et al., 83-94. Tartu: Tartu Univ. Press.

De Cleen, B., and N. Carpentier. 2010. Contesting the populist claim on "the people" through popular culture: The 0110 concerts versus the Vlaams Belang. Social Semiotics 20: 175-196.

De Wever, B. 2015. De Wever: "alle ismes zijn relatief en racisme is dat ook". In Ter Zake, ed. A. Beck. http://deredactie.be/cm/vrtnieuws/videozone/programmas/terzake/2.38146?video=1.2280917.

Essed, P. 2001. Everyday racism: A new approach to the study of racism. In Race critical theories, eds. P. Essed and T. Goldberg, 176-194. Oxford: Blackwell.

Essed, P., and I. Hoving. 2014. Innocense, smug ignorance, resentment: An introduction to Dutch racism. In Dutch racism, eds. P. Essed and I. Hoving, 9-30. Amsterdam: Editions Rodopi.

Foucault, M. 1969. The archaeology of knowledge. London: Routledge.

Ghorashi, H. 2014. Racism and "the ungrateful other" in the Netherlands. In Dutch racism, eds. P. Essed and I. Hoving, 101-114. Amsterdam: Editions Rodopi.

Glynos, J., and D. Howarth. 2007. Logics of critical explanation in social and political theory. London: Routledge.

van der Haar, M., and D. Yanow. 2013. People out of place: Allochthony and autochthony in the Netherlands' identity discourse - metaphors and categories in action. Journal of International Relations and Development 16: 227-261.

Hesters, D. 2011. Identity, culture talk \& culture, 563. Leuven: KULeuven, Faculteit sociale wetenschappen.

Homans, L. 2014a. Beste Peter Verlinden. De Standaard.

Homans, L. 2014b. Racisme is geen excuus om eigen verantwoordelijkheid te ontlopen (open brief van Liesbeth Homans aan Samira Azabar). Kif Kif. Antwerpen.

Homans, L. 2016. Ik overstijg het wij-zij denken. En u? De Morgen. 
Homans, L., and S. De Ridder. 2013. Liesbeth Homans: 'voor het eerst ben ik echt gelukkig' Sven De Ridder: 'ik ben altijd gelukkig'. In De Standaard, eds. B. Bultinck and J. Faes. http://www.standaard. be/cnt/dmf20130814_00692921.

Howarth, D. 2005. Applying discourse theory: The method of articulation. In Discourse theory in European politics: Identity, policy and governance, eds. D. Howarth and J. Torfing, 316-349. New York: Palgrave/Macmillan.

Jacobs, D., and A. Rea. 2006. Construction and import of ethnic categorisations: Allochthones in the Netherlands and Belgium.

Jacobs, D., and S. Rummens. 2003. Wij zeggen wat ù denkt: extreem rechts in Vlaanderen en nieuw radicaal-rechts in Europa. Tijdschrift voor empirische filosofie 4: 41-59.

Jta. 2014. Dewinter: 'probleem is niet vergrijzing, maar verbruining'. De Standaard, May 18. http:// www.standaard.be/cnt/dmf20140518_01109783.

Laclau, E., and C. Mouffe. 1985. Hegemony and socialist strategy: Towards a radical democratic politics. London: Verso.

Lentin, A. 2014. Post-race, post politics: The paradoxical rise of culture after multiculturalism. Ethnic and Racial Studies 37: 1268-1285.

Maly, I. 2007a. Culturenpolitiek, media en verrechtsing. In Cultu(u)r(en)politiek: over media, globalisering en culturele identiteiten, ed. I. Maly, 243-247. Antwerpen: Garant.

Maly, I. 2007b. De botsing der beschavingen. In Cultu(u)r(en)politiek, ed. I. Maly, 93-108. Antwerpen: Garant.

Maly, I. 2009. De nieuwe politieke correctheid. In Een leeuw in een kooi: de grenzen van het multiculturele Vlaanderen, eds. K. Arnaut, S. Bracke, B. Ceuppens, S. De Mul, N. Fadil, and M. Kanmaz, 164177. Antwerpen: Meulenhof.

Maly, I. 2012. N-VA: Analyse van een politieke ideologie. Berchem: EPO.

Maly, I. 2016. 'Scientific' nationalism: N-VA and the discursive battle for the Flemish nation. Nations and Nationalism 22: 266-286.

Moffitt, B. 2016. The global rise of populism: Performance, political style and representation. Stanford: Stanford Univ. Press.

Nimako, K., A. Abdou, and G. Willemsen. 2014. Chattel slavery and racism: A reflection on the Dutch experience. In Dutch racism, eds. P. Essed and I. Hoving, 33-51. Amsterdam: Editions Rodopi.

van der Pijl, Y., and K. Goulordava. 2014. Black pete, "smug ignorance," and the value of the black body in postcolonial Netherlands. New West Indian Guide/Nieuwe West-Indische Gids 88: 262-291.

Prins, B. 2002. The nerve to break taboos: New realism in the Dutch discourse on multiculturalism. Journal of International Migration and Integration 3: 363-379.

Prins, B., and S. Saharso. 2010. From toleration to repression: The Dutch backlash against multiculturalism. In The multiculturalism backlash: European discourses, policies and practices, eds. S. Vertovec and S. Wessendorf, 72-91. Oxon: Routledge.

Reisigl, M., and R. Wodak. 2001. Discourse and discrimination: Rhetorics of racism and antisemitism. London: Routledge.

Romm, N.A. 2010. Conceptualizing new racism in relation to old-fashioned racism: Concepts and research approaches. In New racism: Revisiting researcher accountabilities, ed. N.A. Romm, 33102. Dordrecht: Springer.

Rothenberg, P.S. 2015. White privilege: Essential readings on the other side of racism (5th ed.). Houndmills: Macmillan.

Sakki, I., and K. Pettersson. 2016. Discursive constructions of otherness in populist radical right political blogs. European Journal of Social Psychology 46: 156-170.

Shi-xu, K. 2016. Cultural discourse studies through the journal of multicultural discourses: 10 years on. Journal of Multicultural Discourses 11: 1-8.

Van Dijk, T. 1992. Discourse and the denial of racism. Discourse \& Society 3: 87-118.

Van Dijk, T.A. 2000. Ideologies, racism, discourse: Debates on immigration and ethnic issues. In Comparative perspectives on racism, eds. J. ter Wal and M. Verkuyten, 91-116. Alderschot: Ashgate.

Verschueren, J. 2011. Ideology in language use: Pragmatic guidelines for empirical research. Cambridge: Cambridge Univ. Press. 
Vertovec, S., and S. Wessendorf. 2010a. Introduction. In The multiculturalism backlash: European discourses, policies and practices, eds. S. Vertovec and S. Wessendorf, 1-31. Oxon: Routledge.

Vertovec, S., and S. Wessendorf. 2010b. The multiculturalism backlash: European discourses, policies and practices. Oxon: Routledge.

Wetherell, M. 1998. Positioning and interpretative repertoires: Conversation analysis and post-structuralism in dialogue. Discourse and Society 9: 387-412.

Wetherell, M., and J. Potter. 1988. Discourse analysis and the identification of interpretative repertoires. In Analysing everyday explanation: A casebook of methods, ed. C. Antaki, 168-183. London: Sage.

Wetherell, M., and J. Potter. 1992. Mapping the language of racism: Discourse and the legitimation of exploitation. New York: Harvester Wheatsheaf.

Wodak, R. 2009. The semiotics of racism: A critical discourse-historical analysis. In Discourse, of course: An overview of research in discourse studies, ed. J. Renkema. Amsterdam: John Benjamins.

Yilmaz, F. 2012. Right-wing hegemony and immigration: How the populist far-right achieved hegemony through the immigration debate in Europe. Current Sociology 60: 368-381.

Zienkowski, J. 2014. Articulating metalinguistic and political awareness in Flemish discourses on integration and allochthony. Journal of Political Ideologies 19: 283-306.

Zienkowski, J. 2016. Re-articulating critical awareness about racism in public discourse: Changing one's mind on the Black Pete debates in the Netherlands. In Evaluation in media discourse: European perspectives, eds. R. Breeze and I. Olza, 227-264. Bern: Peter Lang.

Zienkowski, J. 2017. Articulations of self and politics in activist discourse: A discourse analysis of critical subjectivities in minority debates. Cham: Palgrave Macmillan. 